\title{
2
}

\section{Transnational Solidarity Organisations in Contemporary Greek Civil Society: Vibrant, Multifarious and Politicised}

\author{
Kostas Kanellopoulos, Christina Karakioulafi, \\ Pinelopi Alexandropoulou, and Giorgos Soros
}

\section{Introduction}

Greece has experienced striking growth in civil society/social movement organisations in the past decade, mostly as a result of the serious socioeconomic and political impact of the global economic crisis of 2008 the subsequent Eurozone crisis, as well as the refugee crisis of 2015-2016, when the country served as the major gateway to Europe for the largest inflows of migrants/refugees from Asia and Africa in the post-World War II period.

In the 2008-2016 period, the Greek economy lost more than 25\% of its gross domestic product, while unemployment rose to $25 \%$ and to

\footnotetext{
K. Kanellopoulos $(\bowtie) \bullet$ C. Karakioulafi $\bullet$ P. Alexandropoulou $\bullet$ G. Soros Department of Sociology, University of Crete, Crete, Greece e-mail: kanellopoulosk@social.soc.uoc.gr; karakichr@uoc.gr; sorosg@social.soc.uoc.gr 
more than $60 \%$ for the younger generation. ${ }^{1}$ Greek society has only faced situations such as those during or after war, but this time, the disaster occurred during peacetime. The implementation of Troika Memoranda and harsh austerity policies to save Greece from exiting the European Union (EU), in spite of a national protest campaign against such policies (Diani and Kousis 2014; Kousis 2016), had severe impacts on the national population. Over a million people lost their jobs, social and health care was minimised due to cuts in public spending and most Greeks became frustrated and desperate (Featherstone 2011; Matsaganis 2014; Matsaganis and Leventi 2014). Traditionally, the Greek family acts as an informal welfare provider, but families and households were also affected by the crisis (Lyberaki and Tinios 2014). In 2013, only one jobless worker in ten had access to unemployment benefits and there were hundreds of thousands of households without any employed member. Against the backdrop of economic disaster, Troika Memoranda/austerity policies and the partial inability of the Greek welfare state to respond, a wide variety of solidarity-oriented groups and organisations surfaced in the country, offering direct support actions aiming to cover basic and everyday needs (see Kavoulakos and Gritzas 2015; Kousis et al. 2018; Loukakis 2018; Malamidis 2018).

In addition to a wide variety of alternative action groups and organisations (Kousis et al. 2018) rising after harsh austerity policies, pro-refugee/ migrant groups surfaced across the country to address their needs, especially during the refugee crisis of 2015-2016. According to the United Nations High Commissioner for Refugees (UNHCR), 851,319 migrants arrived in Greece during 2015, whereas starting from 5 May 2016, 155,765 arrivals were recorded.

The interviews we conducted in Greece are very much set in a context of economic turbulence combined with an urgent need for humanitarian support of large numbers of refugees. How did Greek civil society intervene? And furthermore, what effect did the dual crisis have on triggering and shaping local informal and small transnational solidarity organisations (TSOs)?

\footnotetext{
${ }^{1}$ https://data.oecd.org/greece.htm (access 26 October 2016).
} 
This chapter pays particular attention to how this vibrant and politicised civil society looks "from the inside". More specifically, it aims to show how TSOs in Greece have experienced the dual crisis, how they practise transnational solidarity and, even more so, how their scope became transnational and more open to people from diverse backgrounds. Additionally, we aim to link the findings of these interviews with a broader theoretical concern regarding the evolution of Greek civil society during these difficult years.

The chapter is based on data derived from the context of the TransSOL project (TransSOL 2016). ${ }^{2}$ The purposive sample is comprised of 30 indepth interviews with representatives of informal, locally oriented and social movement TSOs, 10 from each of the three fields, namely immigration, disabilities and unemployment.

\section{Theoretical, Conceptual Issues: Greek Civil Society Organisations and Transnational Solidarity During Hard Times}

Based on historical studies and dependency theory, scholars claimed that after the Greek Revolution of 1821 and throughout the nineteenth and twentieth centuries, a hypertrophic and in large part ineffective state was formed, leaving too little space for an autonomous civil society to flourish (Tsoukalas 1993; Mouzelis 1986, 1995). Civil society organisations are in large part controlled by the political parties and therefore are vulnerable to state interventions. In a situation like this a hypertrophic state tends to coincide with an atrophic civil society (Mouzelis 2007).

Critics of this view claimed that in terms of authoritative functioning, the Greek state is not ineffective and the Greek civil society is not that weak. Quite the contrary and following a neo-Gramscian conceptualisation, Greek civil society might be seen as a vibrant theatre where the struggle over political and cultural hegemony of various actors is taking

\footnotetext{
${ }^{2}$ Results presented in this chapter have been obtained within the project "European pathts to transnational solidarity at times of crisis: Conditions, forms, role models and policy responses" (TransSOL). This project has received funding from the European Union's Horizon 2020 research and innovation programme under grant agreement No 649435.
} 
place (Voulgaris 2006). Other authors criticise the dominant argument for failing to consider the strong role of trade unions and business associations in the definition of civil society (Iordanoglou 2013).

The same conclusion of an actually strong Greek civil society is drawn in social movement studies, demonstrating the recurrent presence and active involvement of citizens in public affairs (Kousis 1999; Simitis 2002; Afouxenidis 2006; Botetzagias 2006; Kanellopoulos 2009; Kandylis and Kavoulakos 2011; Papadopoulos and Fratsea 2014). Such studies have shown how the strong intervention of Greek civil society not only is independent from the state but has also managed to affect the Greek political system. Mass protests and numerous strikes occurred against the austerity policies and the neoliberal reforms that were embedded in the Greek-Troika "Memoranda of Understanding" (MoUs) (Kousis 2013; Diani and Kousis 2014; Kanellopoulos et al. 2017; Roose et al. 2017). These protests did not manage to change the MoUs' policies, but they certainly contributed to the realignment of the political system (Kanellopoulos and Kousis 2018; Serdedakis and Koufidi 2018). Additionally, a closer look at the interactions between social movements and political parties in Greece would reveal that these two are historically parallel phenomena and the interchangeable influence of one over the other does not account for an atrophic civil society (Kanellopoulos 2018).

Recent reformulations in the literature include interest groups and social movements in their definition of civil society. Sotiropoulos (2017) argues that Greek civil society had already become stronger and more autonomous from state and partisan control before the eruption of the economic crisis. The crisis accelerated these tendencies. Greek civil society in all its forms, non-governmental organisations (NGOs) and voluntary associations, trade unions, local collectives and social movements, have increased their presence and are now more independent from the state and political parties than they used to be pre-crisis (Sotiropoulos and Bourikos 2014; Simitis 2014; Huliaras 2015; Sotiropoulos 2017).

Following a strong national protest campaign against Troika Memoranda and austerity policies, numerous civil society solidarity (direct action) initiatives were created in the decade of the crises in Greece, by a wide variety of groups and organisations to assist natives or migrants, either horizontally or vertically, or both, to cover daily, basic needs (Kavoulakos and Gritzas 2015; Kousis et al. 2018; Loukakis 2018; 
Malamidis 2018). Recent quantitative work (Kanellopoulos et al. 2020; Kousis et al. 2020) based on a comparative analysis of organisational website material shows that transnational solidarity organisations tend to be embedded at the local community level.

They reflect an active civil society evolving outside the clientelistic framework of previous decades and driven primarily by the dual crisis of the last decade. Given the lack of qualitative works on transnational solidarity organisations, this chapter is particularly interested in filling this gap and offering an exploratory account of the drivers of transnationally oriented solidarity organisations in Greek civil society. Have external factors been more important towards their development? Has the refugee crisis exerted more of an influence than the Eurozone crisis and the subsequent harsh austerity policies? Furthermore, as the dual crisis appears to have augmented and accelerated this evolution of solidarity organisations, what other factors have influenced their development? What role did grievances, or previous experience, or collective learning play?

\section{Data and Method}

Following TransSOL criteria for the qualitative study of TSOs, our sample consists of 30 in-depth interviews with informal, non-professional groups/organisations, NGOs without paid staff or with very few staff, operating at the local or regional level, or protest-oriented groups/organisations. These involved both "charity/practical help/service-oriented" and "protest/social movement/policy-oriented" groups/organisations (see Lahusen et al. Introduction in this volume). ${ }^{3}$ More than half of the groups interviewed characterise themselves as protest/policy-oriented (18 out of 30), while the remaining 12 are oriented towards charity/practical help. In terms of organisational structure and transnationality, differences are visible across the issue-fields.

Regarding their transnational and organisational features, in the disability field TSOs tend to have a formal organisation structure and more international collaborations with other organisations compared to TSOs

\footnotetext{
${ }^{3}$ For more information on sampling, see: https://blogs.uni-siegen.de/transsol/files/2016/12/ Integrated-Report-on-Reflective-Forms-of-Transnational-Solidarity.pdf
} 
in the other two fields; in the crises period, they offer solidarity to migrant/refugee groups. In the unemployment field, they tend to have a more horizontal, grassroots organisational structure and they largely resemble social movement groups. Although less often than the disability TSOs, they do collaborate with similar groups outside Greece, while they tend to be transnational in their claims and beneficiaries. In the migration field, we interviewed groups both of the more formal type (NGOs) and of the more horizontal one (protest-oriented); in addition to supporting migrant/refugee groups, some also have transnational supporters.

Overall, the most common transnational activity of the TSOs under study-according to the criteria set in the TransSOL project (Kousis et al. 2020) — is the provision of help to migrants/refugees in the three fields. In addition, the unemployment TSOs, most of which are radical trade unions, follow a traditional internationalist discourse. The TSOs in our sample are involved in solidarity actions across fields; they try to help all those who are in need, including migrants/refugees, while directing their claims to the Greek state in a critical manner.

Compared to the other two fields, it was more difficult to find interview partners for the migrant/refugee field due to their extremely limited time, which was the result of increasing, urgent needs in the field. Also, some of the groups in the migrant/refugee and the unemployment fields rejected the opportunity to collaborate with an official institution.

The sections that follow present the main issues that TSOs focus on as their primary challenges during the crises years, the activities they organise and the target groups they offer their support to, as well as their cooperation practices, based on the interview material. The concluding section highlights and discusses the findings in relation to the theoretical framework.

\section{TSOs' Views on the Crises in Greece and the Related Challenges}

There was a common understanding among all the TSOs we interviewed that the economic crisis and all the MoUs imposing severe austerity policies in Greece had a negative impact on all social fields. This situation led 
most of our TSOs to reorient their action and try to adapt to actions to cover different target groups in need.

The TSO representatives pointed to three main issue areas raising challenges during the crises period: (1) welfare and labour, (2) resources and state policies, and (3) collective learning, raising awareness, openness to others and creation of solidarity groups.

\section{Welfare and Labour}

To begin with, welfare benefits for the disabled and state funding to solidarity organisations in the disability field were reduced while the needs were increased since a growing number of disabled people and their families could not afford to pay for certain health care-related services. Additionally, growing unemployment and economic pressures increased the number of people suffering from mental distress and depression. The sharp increase in the number of people living under the poverty line created a population in need, and some solidarity organisations in our sample from the disability field decided to shift their attention and also direct their services towards these people; for instance, organisations helping disabled children also helped poor families without disabled children that approached them.

As expected, a consistent theme across each of the TSOs we interviewed in the unemployment field was the negative impact of the financial crisis and the austerity measures that followed, on both unemployment and workers' rights. The unemployment rate in Greece is now the highest among all EU member-states, but the Greek welfare state was unprepared and ill-equipped to provide help to this enormous current of newly unemployed who soon turned into long-term unemployed. New legislation was passed that lowered the bargaining power of trade unions and facilitated the firing of workers. The minimum wage diminished, all wages were severely cut, working hours became longer, countless businesses were closed down, and hundreds of thousands of employees were made redundant while unemployment benefits were also significantly reduced. According to our respondents, one of the main aspects of the 
"Memoranda" terms was the worsening of labour conditions and workers' rights:

The laws that are voted are increasingly helping collective redundancies and completely dismantling collective agreements and procedures to defend employees, so in reality what is happening is that employers are being given the opportunity to lay off more and more people and to lead more and more people to unemployment. (Unemp1 09/2016)

Due to the severity and the length of the economic recession, the whole population in Greece, to different degrees, of course, was significantly affected.

According to TSO representatives of radical trade unions, trade union membership was reduced and many of the remaining members became inactive during the economic crisis period. One direct negative effect of the crisis on trade unionism is that the closure of many enterprises meant also the closure of the unions that operated within them. As an interviewee said:

When an old enterprise closes and a new one starts, that also means that unionism in the new enterprise has to start from the beginning and under worse conditions since new employees are afraid to get unionised for fear of losing their jobs. (Unemp2 09/2016)

Welfare cuts and worsening conditions on the labour market were also mentioned as important effects of the crisis by most of the organisations from the migration field. Especially during the refugee crisis of 2015, these TSOs had to act and provide welfare precisely due to the deterioration of the Greek welfare state.

\section{Organisational Resources and State Policies}

Crisis-led austerity policies affected the funding and operation of civil society organisations, including TSOs, according to many of our interviewees. The sharp reduction in income led to decreased citizen donations to civil society organisations: 
Before the crisis, at a simple fund-raising at a hairdresser's shop, we could easily raise 500 euros; now the same event would hardly gather 50 euros. (Disab5 09/2016)

However, in terms of state and intergovernmental funding, TSOs engaged in fighting social exclusion and promoting the integration of refugees and immigrants seem to have benefitted from the dual crisis. Since significant amounts of money were available by the UN and the EU for organisations dealing with refugees, even some small organisations from the disabilities field shifted their aims in order to survive. As an interviewee said:

When the crisis erupted, we thought that we were about to close, but instead our activities and our cycle of work multiplied ten times. (Disab6 09/2016)

Concerning policymaking during the economic crisis, a new law taxing donations made them even more difficult to obtain, by both individuals and private companies. In addition, although new legislation regarding social economy initiatives - that also affect solidarity groupswas implemented, the status of volunteers remains vague. Besides narrow economic claims, what many of our interviewees ask from policymakers is a regulative framework, even at the EU level, and better coordination and allocation of resources for civil society organisations.

Referring to the policies of the Greek state, even though the majority do not completely disapprove of the way it responds to the dual crisis, our interviewees agreed that its actions are not enough or sufficient to cope with the challenges properly:

Coordination of information is necessary because too many actors are involved and many times, some beneficiaries don't receive anything while others receive a lot from many actors. (Disab1 09/2016)

Furthermore, the coincidence of economic and refugee crises has created tensions and significant problems for the operation of some TSOs. As was aptly stated by one interviewee: 
All state funding and attention is now going to refugees, which I understand since I was a refugee of war in 1974. I agree, but on the other hand, you cannot let the disabled starve. (Disab10 10/2016)

\section{Collective Learning and New Initiatives}

Has the crisis led to raising awareness for labour, disability and human rights? Almost all of our interviewees in all three fields stressed the effect the crisis has had on raising people's awareness and consciousness. The severe economic crisis is raising awareness in the sense that people start to perceive themselves as members of the society and not as isolated individuals. As such, they have human and social rights. Even more so, the social groups that are the most vulnerable and the most affected by the dual crisis, like the unemployed, the disabled and the migrants, have serious problems and rights that have to be highlighted and protected. Especially among the trade unions that lost members, this cognitive effect is regarded as very important. The economic crisis has increased solidarity among employed and unemployed workers since economic strain and worsening working and living conditions are common to both groups.

Another of the few positive consequences of the crises in Greece for the sector of solidarity organisations in all fields is the rise in the number of volunteers. Many young people who are unemployed have decided to devote time to volunteering because this raises their self-esteem while many others feel the need to help their fellow humans in need. The latter was especially apparent during the recent refugee crisis when many Greeks spontaneously offered many kinds of help to newly arrived refugees. But, on the other hand, the number of volunteers who are specialised professionals, and who are especially needed in the disabilities field, has not increased due to lack of time since they have to work more to retain their standard of living.

Furthermore, some of the solidarity groups in the unemployment and migration samples were created during and because of the crisis, while membership in one anarcho-syndicalist group in our sample increased. These groups, regardless of their formal or informal character, were made precisely in order to help unemployed newly arrived migrants and socially excluded people. 
Many of our interviewees in the unemployment field also emphasised the positive impact the crisis has had on workers' attitudes towards selforganising. The severity of the crisis and the hostility of the state have made the workers and the unemployed realise that they should selforganise in order to achieve better labour and living conditions. As one interviewee aptly stated:

With the crisis it becomes clearer to the people that only through their selforganisation can they achieve things since legislation is becoming all the more flexibilisation-oriented and against workers. (Unemp3 09/2016)

In addition to the three solidarity-related issues raised by TSO representatives, many of our interviewees observed that the dual crisis has led to an increase in the popularity of extreme right-wing and fascist political parties, creating burdens on the notion of social solidarity and cohesion while making the actions to protect democracy and human rights all the more essential. One interviewer noted, however, that there has been a positive change regarding laws concerning racist violence and equality from 2013 to 2015. But starting in 2016, and with the agreement between the EU and Turkey, there has been a rapid deterioration, and vulnerable social groups, like those of the immigrants, have found themselves in a very difficult situation, in view of extreme right populism.

\section{Activities: Missions and Target Groups}

As is expected, issue-fields play a significant role in differentially affecting the related TSOs in our sample. In the disability field, TSOs are comprised of specialised professionals and people who are relatives of disabled people and share a special interest. In the migration field, TSOs involve experienced and long-term advocates of human rights, plus many newcomers who have found employment in the rapidly expanding Greek third sector. In the unemployment field, TSOs involve many radical groups comprised of anarchists and devoted socialists.

The activities of each TSO, depending on the issue-field it is operating in, are closely interrelated with its organisational pattern. TSOs, mainly 
in the disability and migration issue-fields, with a more formal organisational structure are dedicated to practical help in the field, raising awareness for the rights and needs of their target groups and influencing policymaking. Those TSOs, mainly from the unemployment issue-field, that apply a more horizontal and anti-hierarchical organisational structure are more protest-oriented and direct their activities and practical help offered across fields. In short, on the one hand, more formalised TSOs are also more specialised with regard to their target groups and are also more service-oriented. On the other hand, less-formalised TSOs target broader, or multiple constituencies, and they are also more politicised.

Besides differences due to their specialisation, the interviewees of the TSOs in all three fields seem to have many attributes in common. They are determined people who believe in civic engagement. They try to offer help to people who are in need without discrimination. At the same time, they are politically active and try to influence policymaking in their field, and even beyond.

\section{Activities and Organisational Patterns}

A main finding for the TSOs across the three fields is that they all carried out actions in response to the urgent needs arising in the migrant/refugee detention facilities, but also activities that focus on long-term treatment of these problems, through influence and alteration of policies. More specifically, the activities included collecting clothes, medicine and food through donations and distributing them, mostly in the detention camps with the help of volunteers, to migrants and refugees. These actions of responding to urgent needs were taken by TSOs in all three fields (immigration, disabilities and unemployment).

Migration TSOs focus their actions on providing education to migrants and refugees, to both adults and minors, through teaching foreign languages. In some cases, the teachers are themselves refugees in these facilities. Similar activities include work with children in the detention camps, through creative workshops and organised events (for instance, public documentary viewings and giving lectures in schools) that aim to inform and spread awareness to the rest of Greek society. We also spotted 
initiatives like the one started by an NGO located in Athens, where in collaboration with state actors, local people and the UNHCR offer housing, along with the right to legal employment, to refugee families, for the period of time in Greece, while their cases for asylum or family reunification are being processed.

Migration TSOs also take several actions of a more indirect character that focus on the task of providing information and spreading awareness about the problems that migrants and refugees face in Greece, but also focus on pressuring the policymakers, in order to achieve alterations in migration-relevant policies. This process is mainly conducted through writing reports that are submitted both to the relevant state actors and to the Council of Europe. The ultimate goal of these actions is to solve the problems that migrants have to face, policy-wise, and a gradual policy shift into a more anthropocentric and solidary form.

Finally, migration TSOs use protest-oriented action, like occupation of public property in order to provide shelter for refugees and migrants, as well as rallies that aim to protest against border closure, where Greeks and migrants/refugees aim to put pressure on the responsible state actors to achieve swift alterations to relevant policies.

Disability TSO representatives involve parents or relatives of disabled persons in some cases while depending on volunteers in various sectors who have helped in the past or who have expressed a high commitment to volunteering and community help. As one interviewee stated:

...I did it before but with the crisis and all that you are saying to yourself: here you have to help. (Disab4 09/2016)

The main activities of disability TSOs vary from mental health and social care provision, support of people living with HIV/AIDS and genetic disorders, food provision and provision of prognostic medical tests, support of children's rights and children in need and psychiatric reform to support of people with disabilities, victims of social exclusion and victims of racist discrimination. Most of the TSOs employ a primary activity, but they also employ some others since in times of crisis, needs often intersect. As our interviewees said:

Volunteerism doesn't have borders or sectors. (Disab4 09/2016) 
You may have a family with a grandmother who has health problems, a mother who has psychological problems, a kid facing learning problems at school and a father who is unemployed... (Disab1 09/2016)

Most of these interviewees stated that their groups are actively involved in a dialogue with political institutions at all levels. One group contributes to multiculturalism in a poor neighbourhood that is "controlled" by far-right groups. Another group deliberately fights discrimination against persons living with HIV/AIDS. Almost all groups press for the expansion of state expenditure on health and social care and, in a way, ask for justice for those in need:

Injustice is a big issue. These are wounded people. (Disab6 09/2016)

Unemployment TSOs, but sometimes also disability and migration ones, address unemployment issues by providing practical help and some sort of services to their members, whether they are employed or unemployed (as well as to refugees and immigrants). In contrast to charities and practical help or service-oriented organisations, these TSOs adopt a rather political orientation. Hence, the dominant features of their activities remain political intervention and organising political action. In fact, most of the unemployment TSOs have a radical orientation, and they usually engage in protest events and social movement campaigns. They intervene in labour disputes, but their members are committed not only to protecting and advancing their organised and sectoral interests but also to advancing labour and working-class rights, including migrant and refugee rights, regarding them as the most vulnerable part of the working class and therefore in need of support.

\section{(Multi-)target Groups and Solidarity Action Repertoires}

An important shift has occurred since 2009 when Greece entered the economic crisis. Until 2009, the basic recipients of the activities of migration solidarity groups were homeless people, undocumented immigrants, 
drug addicts and Roma. After 2009, as a result of the crisis, these target groups expanded to include increasing number of Greek citizens. Many of the migration TSOs providing support to migrants have become multi-target organisations helping a broader spectrum of beneficiaries. As migration TSOs stated, starting from 2010, they came across a shift in their target groups, since a large number of Greek citizens, suffering the consequences of the financial crisis, were added to the existing recipient groups. Moreover, since 2015, massive migration inflows brought to the surface the urgent call to provide help to a large number of migrants and refugees in Greece. Informal solidarity groups, as well as NGOs, mostly fulfilled this role.

Most of our interviewees across the three fields made it clear that their target group was not something static, but it was in a state of flux depending on the needs and the problems that were arising in Greek society. Irrespective of their field and focus of activity, their main goal was to play a supplementary role to that of the state when it comes to providing help to the most vulnerable social groups. In most cases, TSOs in the three fields are open to individuals who live under precarious conditions and seek their help:

We are open to groups that come to us, because you don't need to make an appointment to come to the organisation or the day shelter. You knock on the door during the shifts and you come. So, in a sense, it's not us who choose the target group, but it's the people who come to us, seeking help. (Migr1 09/2016)

The openness towards diverse target groups and people in need is also well exemplified by unemployment TSOs in our sample, most of which are grassroots-level unions. They are deliberately trying to represent the growing number of unemployed during those years of the economic crisis, and defend their rights. Another target group of the unions are the immigrants since most of them do not have full civil rights in Greece. Many are precarious workers and very few are unionised. Therefore, the aim of most of our unions is to unionise, come closer and represent the working rights of the immigrant population. 
Regarding the repertoire of TSO actions, most interviewees pointed to the learning processes they went through during these actions. The main reason why TSOs had to expand and/or experiment with new activities was that Greece and Europe found themselves in terra incognita, especially when it came to the refugee crisis, and this led the people involved to experiment with different activities in order to provide the best possible help.

Some of the actions that our respondents perceived as innovative included the aforementioned housing programme for refugee families, but also pressuring state actors for policy alterations. These had successful outcomes and gave the recipients of this innovative action the right to legal employment for as long as they stayed in Greece.

It's very innovative! Think about it! Asylum seekers that come from a country where there is war...they apply for asylum, come to Greece and we give them a key to a house to call their own! And since we were trying to avoid benefit policies, we collaborated with other groups and the law has now changed, so these people are entitled to legal employment for as long as they stay here! (Migr1 09/2016)

Other TSO activities involve the development of special shelters for unaccompanied minors, away from the detention camps, in order to keep them safe from trafficking and other problems that they could possibly face, and also initiatives that aim to help migrants and refugees come together through the calling out for participation in several rallies, meetings, and the occupation of public buildings. What is new here is the fact that protest groups translate their callings and information sheets concerning their actions into languages like Arabic or Farsi, with the help of migrant volunteers.

An important activity held by one TSO is the operation of a school for immigrants inside the detention camp:

It's a school that runs from 9:00 to 22:00. We have been there for five and a half months now; there are 1400 minors. We got to help all the refugee teachers there to coordinate and teach... Following meetings we had with the parents, where we told them how kind and smart their kids are and 
how essential it is for them to get educated, we had 50 more subscriptions the following day. The same parents asked us to create another class for adults, to teach them Arabic and also a class for folklore music and knitting. (Migr2 07/2016)

A rather innovative approach, at least in the Greek context, is taken by a TSO that mediates between those enterprises and individuals that are willing to offer food (for instance, from weddings, celebrations and the like) and those institutions that need food to offer to beneficiaries (municipalities, church, etc.). The goal is to reduce food waste and also reduce the cost of doing it since this organisation, unlike food banks, does not store or carry food. This practice has received attention from large food banks in New York and has been presented in the European Parliament. As one of the group's founders stated:

It is need that makes you innovative. (Disab2 09/2016)

Other practices considered innovative by the TSOs are the "expert by experience" techniques. In these cases, people who have themselves suffered from a disability and have received help or mediation now offer help and mediation out of their experience and training. These practices are used by groups that provide support to people living with HIV/AIDS and people with mental diseases like depression. Some TSOs like those dealing with genetic disorders and children's rights consider their services innovative because they offer knowledge to a general public that becomes better informed about these issues.

When asked about the innovative character of their work, most TSOs mention some of their activities and the broader campaigns in which they are taking part. Namely, two interviewees mentioned the open call of the company unions to the consumers to boycott the products of their respective companies during the periods of industrial conflict. Trade union TSOs consider the operation of the bottom-up/grassroots "coordination of first-level unions", which mobilises workers and surpasses the inertia of secondary- and third-level confederations, as an innovation in Greek trade unionism. Other innovative actions they mention include the issuing of unemployment cards to all the members of the unions in order to 
get some discounts, the provision of insurance coverage to those working as self-employed, the entrance of precarious workers to public sector unions and the on-the-spot surveillance of employers to ensure that they do not hire workers without insurance.

In practice, informal TSOs linked to neighbourhood initiatives, name as innovative the delivery of foreign-language and philosophy classes to the unemployed. The interviewee who represented the NGO in our sample from the unemployment issue-field mentioned as innovative the holistic approach they have adapted towards the provision of help to the unemployed with mental illness. According to this approach, the NGO provided psychological support along with classes to help them acquire new skills and technical support in finding a job.

Horizontalism, bottom-up labour mobilisation and direct democracy are among the practices most of our TSO representatives promote and consider as innovative. The workers of one of our groups who occupied their factory that was about to shut down have carried out a practical implementation of the above principles. They are practising mutual help by self-managing the factory, by not employing any hierarchical structure and by distributing and selling their products through social movement channels and not through the market:

In February 2013, we began production with self-management. Here, everything is decided by the employees' assembly, the council of the union has a formal role, it does not have an essential role, everything is decided in the assembly and there are no hierarchies either managerial or otherwise; we are all equal and the endeavour is also to switch all roles either in the production process, or in the representation when needed in some political, social movement type processes. (Unemp5 09/2016)

Of great importance is the fact that, even though the TSOs recognise that refugees and migrants are in the spotlight lately, they all agree that this should not, on their behalf, lead to further segregation of other vulnerable groups. The majority of these TSOs see their activities as supplemental to those of the state, but also as their duty, to denounce policies that lead to further segregation and pauperisation of vulnerable social groups. At the same time, TSO representatives believe that the future of 
solidarity lies in the awakening and action of civil society, against policies that undermine human rights, and also the rallying of groups and individuals against fascist and extreme right phenomena both in Greece and in Europe in general.

\section{Cooperation: Forms, Reasons and Rationales}

The TSOs in all three fields are in general in favour of solidarity, but they understand and practise transnational solidarity in different ways. The more informal groups tend to share few transnational ties due to limited time and resources. It is the NGOs from the three fields that share these kinds of cross-national bondages. Mostly through partnerships with organisations from other European countries, these NGOs share knowledge, participate in international projects and try to attract EU funding. The protest-oriented TSOs in the migration and the unemployment fields perceive transnational solidarity in a more political manner. It is especially the unemployment TSOs that are in favour of a classic labour internationalist orientation, whether or not they have the opportunity and the resources to get involved in any transnational collective action or not.

Concerning the main supporters of our TSOs, this depends on the group's hierarchy and characteristics. More specifically, the NGOs in all fields depend largely on financing from official state actors, the European Commission, UNHCR and a series of European funding programmes, in general. Groups of a different, more protest-oriented and informal nature mostly depend on help from volunteers and donations while they organise activities and bazaars in order to gain funding that will allow them to continue their work.

Clearly, the publicly funded NGOs stressed that the EU was very relevant and involved in their field of action since it was their main source of funding. At the same time, this direct connection to the EU made it easier for these groups to find themselves in dialogue with official state actors and the European Commission, regarding policies that concern their main field of actions. In contrast, the groups that were leaning towards a more protest-oriented and informal character deemed the EU as playing a non-pivotal role in their field of action, out of principle. They 
tend to follow more combative ways (namely through rallies, the establishment of informal solidarity activities and the occupation of public buildings) to criticise EU and national policies that are relevant to their activities. In particular, most of the interviewees from the unemployment TSOs expressed a negative opinion towards the EU. They have argued that the EU is functioning against the interests of the working class. One interviewee said that her group supports exiting the EU from an internationalist, but not a nationalist, vantage point. Most of these interviewees said that the struggle should be against the local bosses. One argued that:

The crucial point is not whether Greece should be inside or outside the European Union, but the position of the workers regardless of whether Greece is inside or not. (Unemp4 09/2016)

TSOs in our sample, however, depend more on the support and donations of ordinary people. Both NGOs and more protest-oriented TSOs agreed that ordinary people are the main supporters of their actions through their participation in and response to their activities. They have also agreed that the state is either inefficient or unable to cope with the challenges regarding the financial and migrant crises.

With the exception of the few TSOs that participated in the research but rejected in principle the possibility of collaborating with the state and state actors, the others are involved in some kind of collaboration with the state, depending on their activities. This collaboration included cooperation for the needs of a project regarding migrants and refugees, collaborating with the district attorney or the police in order to protect unaccompanied minors, or the attempt to gather donations (mainly material goods, like desks or blackboards) for group activities.

When asked about the challenges of transnational collaborations, and collaborations in general, one TSO representative responded that in their group, they employed some criteria in order to start a cooperation:

These criteria are the existence of ethos, respect and transparency: Without these, you cannot help, therefore you cannot collaborate. (Disab3 09/2016)

Transparency is an important criterion for one more organisation that has also raised serious doubts about the possibility of effective 
collaboration between organisations because, according to their experience, many times organisations that operate in the same field develop antagonistic attitudes. But the most intense doubts about transnational collaborations were raised by one interviewee, who has herself been a high-ranking EU official in the past and who represents a solidarity organisation that is very active in transnational projects:

We are living a colonialisation by the big foreign NGOs and the UNHCR...these people are managers...solidarity [for them] is a new business, an innovative business. (Disab6 09/2016)

With regard to beneficiaries, the activities of Greek TSOs across all three fields involve transnational target groups within Greece. This means that their activities involve tailor-made advice and support for beneficiaries with migrant/refugee background in need of help within the country. In contrast, only very few and mostly charitable groups are involved in solidarity activities with individuals living in other countries. However, most of our interviewees perceive solidarity as something that has to be applied on a global level, with the cooperation of organisations and individuals, in order to achieve the best results.

It was clearly stated by all TSO representatives that the collaboration among different solidarity groups was something that was both desired and essential. Many expressed a desire to get involved in broader solidarity networks since this involvement has three main positive outcomes: Firstly, at the practical level, through collaboration, the solidarity actions and the offer of practical support are extended, allowing for the provision of help to a bigger part of the targeted groups. At the same time, collaboration often gives status and the ability to be heard on national and international levels and effectively puts pressure on the policymakers. Lastly, the transnational collaboration that many of the selected groups aim or aimed to achieve gives the people involved in all these groups the ability to be better informed and aware of matters that concern migrants/refugees, the unemployed and the disabled throughout Europe.

In general, the idea of transnational collaboration is something that all the selected groups are open to, although most of them have not actually tried it on a broad scale yet. The main difficulty mentioned by the interviewees regarding collaboration with other groups, on both national and 
transnational levels, was the large effort that is needed in order to coordinate such initiatives. Therefore, TSOs choose to collaborate with groups that share the same philosophy and similar principles as them (e.g., an NGO collaborating with other NGOs, protest groups collaborating with other protest groups that belong to a broader network).

While most TSOs lack the capacity to put transnational solidarity into practice, there are some that are actively committed to it. For instance, there is one TSO operating a factory occupation that is also very active at the transnational level since it is related to other factory occupations and self-management projects and cooperatives in Europe, Latin America and North Africa. Another interviewee mentioned the participation of his group in a transnational collective action against the operation of Sunday trading. As he said:

We are buying books on weekdays and we are reading them on Sundays. (Unemp2 09/2016)

\section{Conclusions}

The interviews we have conducted with TSOs operating in the fields of migration, disabilities and unemployment have provided interesting insights into Greek civil society as it has emerged and developed during the economic and refugee crises. Of course, some of the TSOs existed before the dual crisis. The older ones in all three fields deployed a higher degree of competence and knowledge to implement and advocate better conditions for immigrants, the disabled and the unemployed. But the durability of both crises and the inability of the Greek state to adequately deal with them made the appearance of new civil society groups, especially in the fields of immigration and unemployment, necessary. The newer groups are more prone to innovation, have fewer resources and depend more on volunteerism. Innovation is wanted either because of the lack of resources, due to the economic crisis, or because of the growing need for effectiveness. Some TSOs are operating without any cooperation with the Greek state or EU authorities, and most of them advocate bottom-up solidarity and counterpose it to top-down charity. 
However, we have to note here that the differences between the older and the newer TSOs of our sample are not very significant. The people who created the new TSOs were not new in the migration, disability and unemployment fields. In most cases, they were already active in relevant civil society organisations and social movements (Kavoulakos and Gritzas 2015). It seems that the eruption of the economic and refugee crises in Greece caused an increase in the number of participants in civil society and a transformation of its activities (Tsakatika and Eleftheriou 2013; Vathakou 2015). The dual crisis created new needs and an already vivid civil society tried to cope with them, but without altering its main endogenous characteristics.

The examination of our TSOs shows that both older and newer groups are rather small organisations, unlikely to become large NGOs. Regarding their transnational linkages, it seems that some of them, especially from the disability field, hold weak ties with transnational bodies, while others opt for transnational discourse on more political terms. Overall, their transnational solidarity activities are mainly directed towards migrants and refugees in need of help inside Greece.

The breadth and range of solidarity in Greece appear to have expanded and shifted towards a more transnational one due to external factors, namely the Eurozone and refugee crises. The findings of the interviews with TSOs testify that a vibrant before-crises Greek civil society became also more multifarious and more politicised as a result of internal factors as well. The newly imposed grievances at the backdrop of a deteriorating political framework, previous experience as well as collective learning, led to the growth of the organisational field (more volunteers and new groups) and more voices in regard to issues and demands, as well as openness towards diverse target groups and people.

The expanded solidarity activities are directed at a variety of target groups and are not confined to a sole primary target group. TSOs appear to be very flexible, more open to others and adaptive to new conditions and urgent needs. Additionally, an impressive finding out of these interviews is that Greek TSOs tend to be highly politicised. From mainstream NGOs to informal collectivities, from radical trade unions to small charitable groups, all the TSOs in our sample are "talking politics" while being totally autonomous from the Greek political parties. Either in the form 
of claims' making to the Greek state, or in criticising and trying to influence the policies of any given Greek government, or in referring to internationalism and the need to overthrow capitalism, our TSOs are deeply concerned with and active in politics, thus offering no evidence for those claiming a lack of civil society in Greece or a weakness thereof. Under the dual crisis conditions, our interviewees have also provided some provisional policy recommendations. Namely, they are asking for (1) the Greek state or the EU authorities to intervene more effectively and coordinate some actions especially when many groups overlap in one field, (2) a better and updated legislation regarding volunteerism, (3) more funding and tax exemptions on donations, and (4) the facilitation of smaller groups to operate in the field of refugees since large and transnational NGOs are out of touch with local stakeholders' needs.

The economic and refugee crises have posed, and are still posing, serious challenges to the social cohesion of Greek society. The interview data we have presented in this chapter illustrate the efforts of these TSOs across three issue-fields to meet these challenges. They intervene by employing a variety of means that aim to achieve solidarity. One might assume that through their intervention, these groups develop a transnational dimension that also fits well with the transnational dimension of the challenges they face. This intervention may prove insufficient, but at least it testifies for the evolution and efforts of a vibrant civil society. Contrary to supporters of "the weak civil society" argument, the groups we have interviewed are not controlled by political parties and are strongly criticising the Greek state for its policies regarding the economy and migration. Furthermore, our findings contribute to recent work on alternative solidarity organisations by shedding light and offering new knowledge on them and their transnational dimension.

\section{References}

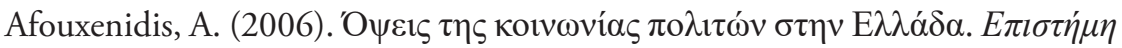
каl Kolvwvía, 16, 163-178.

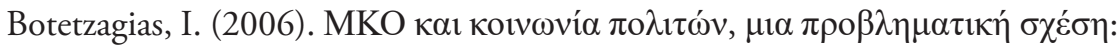

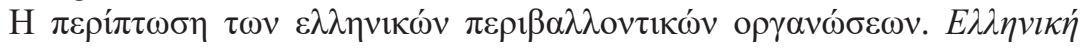

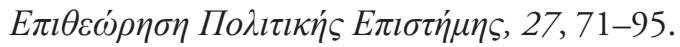


Diani, M., \& Kousis, M. (2014). The Duality of Claims and Events: The Greek Campaign Against Troika's Memoranda and Austerity. Mobilization, 19(4), 387-404.

Featherstone, K. (2011). The Greek Sovereign Debt Crisis and EMU: A Failing State in a Skewed Regime. Journal of Common Market Studies, 49(2), 193-217. Huliaras, A. (2015). Greek Civil Society: The Neglected Causes of Weakness. In J. Clarke, A. Houliaras, \& D. Sotiropoulos (Eds.), Austerity and the Third Sector in Greece: Civil Society at the European Frontline (pp. 9-27). Farnham \& Surrey: Ashgate.

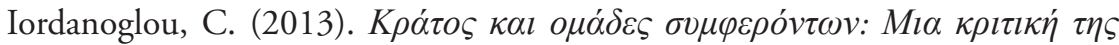

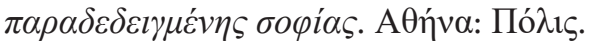

Kandylis, G., \& Kavoulakos, K. (2011). Framing Urban Inequalities: Racist Mobilization Against Immigrants in Athens. The Greek Review of Social Research, 136C, 157-176.

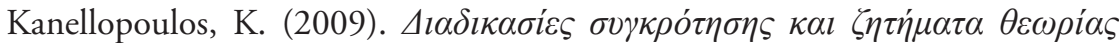

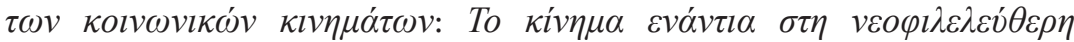

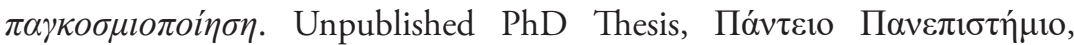
A $\theta$ ท́va.

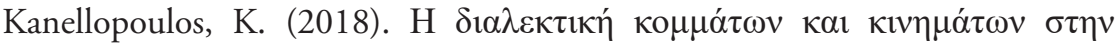

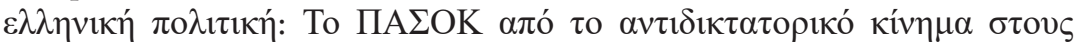

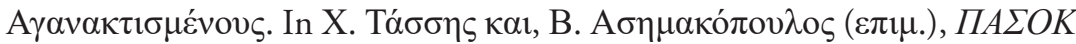

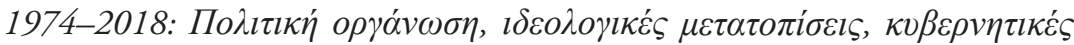

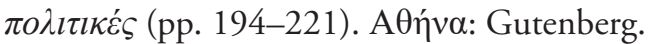

Kanellopoulos, K., \& Kousis, M. (2018). Protest, Elections and Austerity Politics in Greece. In A. Placas \& E. Doxiadis (Eds.), Living Under Austerity: Greek Society in Crisis (pp. 90-112). New York/Oxford: Berghahn.

Kanellopoulos, K., Kostopoulos, K., Papanikolopoulos, D., \& Rongas, V. (2017). Competing Modes of Coordination in the Greek Anti-Austerity Campaign 2010-2012. Social Movement Studies, 16(1), 101-118.

Kanellopoulos, K., Deniz, D., Zschache, U., Loukakis, A., Kousis, A. \& Trenz, H.-J. (2020). Transnational Solidarity, Migrants, and the Refugee Crisis: (In)Formal Organising and Poltical Environments in Greece, Germany and Denmark, Sociological Research Online, https://doi.org/ $10.1177 / 1360780420937030$.

Kavoulakos, K., \& Gritzas, G. (2015). Movements and Alternative Spaces in Greece in an Era of Crisis: A New Civil Society. In N. Georgarakis \& N. Demertzis (Eds.), The Political Portrait of Greece: Crisis and the Deconstruction of the Political (pp. 337-355). Athens: Gutenberg.

Kousis, M. (1999). Environmental Protest Cases: The City, The Countryside, and The Grassroots in Southern Europe. Mobilization, 4(2), 223-238. 


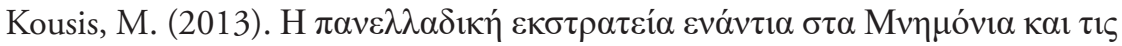

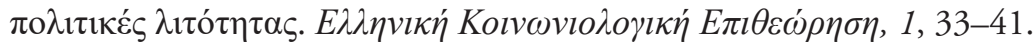

Kousis, M. (2016). The Spatial Dimensions of the Greek Protest Campaign Against Troika's Memoranda and Austerity Measures, 2010-2013. In M. Ancelovici, P. Dufour, \& H. Nez (Eds.), Street Politics in the Age of Austerity: From the Indignados to Occupy (pp. 147-173). Amsterdam: Amsterdam University Press and The Chicago University Press.

Kousis, M., Kalogeraki, S., Papadaki, M., Loukakis, A., \& Velonaki, M. (2018). Confronting Austerity in Greece: Alternative Forms of Resilience and Solidarity Initiatives by Citizen Groups. In J. Roose \& M. Sommer (Eds.), Europas Zivilgesellschaft in der Wirtschafts-und Finanzkrise (pp. 77-99). Wiesbaden: Springer VS.

Kousis, M., Loukakis, A., Paschou, M., \& Lahusen, C. (2020). Waves of Transnational Solidarity Organisations in Times of Crises: Actions, Obstacles and Opportunities in Europe. In C. Lahusen (Ed.), Citizens' Solidarity in Europe. Civic Engagement and Public Discourse in Times of Crisis (pp. 55-84). Cheltenham: Edward Elgar.

Loukakis, A. (2018). Not Just Solidarity Providers. Investigating the Political Dimension of Alternative Action Organisations (AAOs) During the Economic Crisis in Greece. Partecipazione e Conflitto, 11(1), 12-37.

Lyberaki, A., \& Tinios, P. (2014). The Informal Welfare State and the Family: Invisible Actors in the Greek Drama. Political Studies Review, 12(2), 193-208.

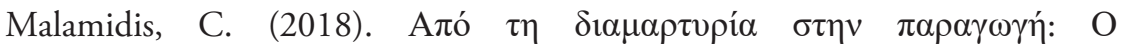

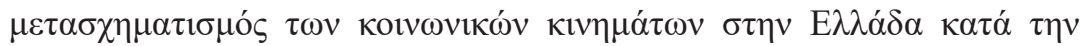

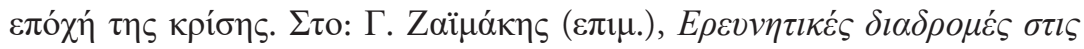

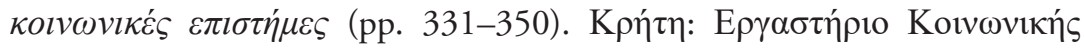

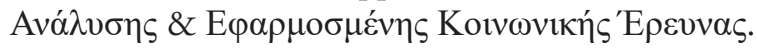

Matsaganis, M. (2014). The Catastrophic Greek Crisis. Current History, $113,110-116$.

Matsaganis, M., \& Leventi, C. (2014). Poverty and Inequality During the Great Recession in Greece. Political Studies Review, 12(2), 209-223.

Mouzelis, N. (1986). Politics in the Semi-Periphery: Early Parliamentarism and Late Industrialisation in the Balkans and Latin America. London: Macmillan. Mouzelis, N. (1995). Modernity, Late Development and Civil Society. In J. Hall (Ed.), Civil Society: Theory, History, Comparison (pp. 224-249). Cambridge: Polity Press.

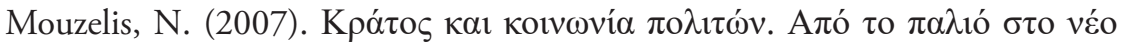

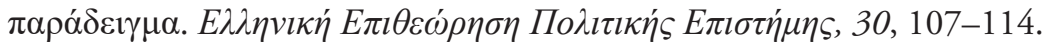




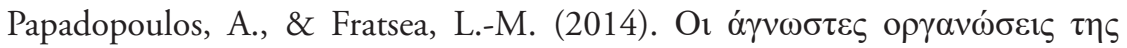

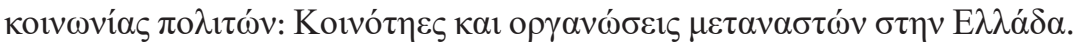

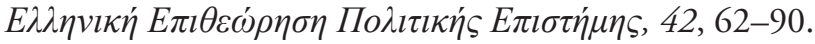

Roose, J., Kanellopoulos, K., \& Sommer, M. (2017). National Anti-Austerity Protests in a European Crisis: Comparing the Europeanizing Impact of Protest in Greece and Germany during the Eurozone Crisis. Journal of Civil Society, 13(3), 284-306.

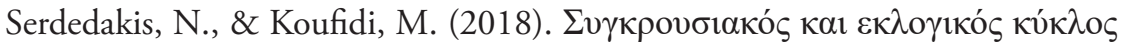

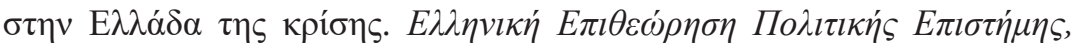
44(1), 7-30.

Simitis, M. (2002). New Social Movements in Greece: Aspects of the Feminist and Ecological Projects. Unpublished PhD Thesis, London School of Economics and Political Science, London.

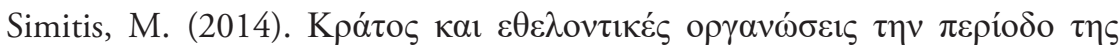

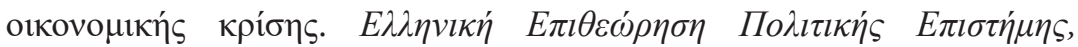
42, 36-61.

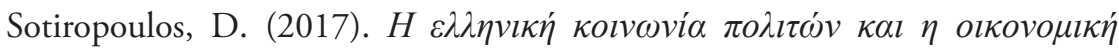

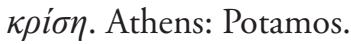

Sotiropoulos, D., \& Bourikos, D. (2014). Economic Crisis, Social Solidarity and the Voluntary Sector in Greece. Journal of Power, Politics and Governance, 2(2), 33-53.

TransSOL. (2016). Work Package 2 Integrated Report on Reflective Forms of Transnational Solidarity. Retrieved from: https://blogs.uni-siegen.de/transsol/files/2016/12/Integrated-Report-on-Reflective-Forms-of-TransnationalSolidarity.pdf

Tsakatika, M., \& Eleftheriou, C. (2013). The Radical Left's Turn Towards Civil Society in Greece: One Strategy, Two Paths. South European Society and Politics, 18(1), 81-99.

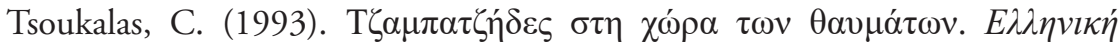

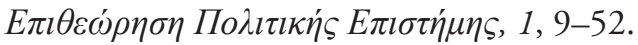

Vathakou, E. (2015). Citizens Solidarity Initiatives in Greece during the Financial Crisis. In J. Clarke, A. Houliaras, \& D. Sotiropoulos (Eds.), Austerity and the Third Sector in Greece: Civil Society at the European Frontline (pp. 167-189). Farnham/Surrey: Ashgate.

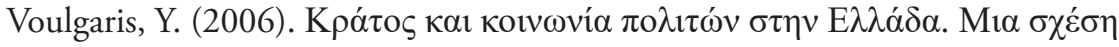

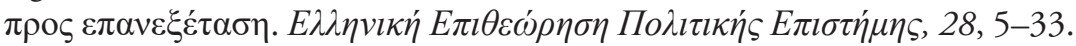


Open Access This chapter is licensed under the terms of the Creative Commons Attribution 4.0 International License (http://creativecommons.org/licenses/ by/4.0/), which permits use, sharing, adaptation, distribution and reproduction in any medium or format, as long as you give appropriate credit to the original author(s) and the source, provide a link to the Creative Commons licence and indicate if changes were made.

The images or other third party material in this chapter are included in the chapter's Creative Commons licence, unless indicated otherwise in a credit line to the material. If material is not included in the chapter's Creative Commons licence and your intended use is not permitted by statutory regulation or exceeds the permitted use, you will need to obtain permission directly from the copyright holder.

(c) (i) 